\title{
ヒトに抢ける小麦アルブミンの単回投与による 食後血糖上昇抑制作用と安全性*
}

\author{
森 本 聡 尚 ${ }^{1}$, 宮 崎 俊 之 ${ }^{1}$, 村 山 隆 二 ${ }^{2}$ \\ 児玉 俊 明**,1, 北 村 育 夫 $^{1}$, 井上 修 二
}

\section{Wheat Albumin with Amylase-inhibitory Activity Suppresses Glycemic Rise after Rice Loading in Human Subjects*}

\author{
Toshihisa Morimoto, ${ }^{1}$ Toshiyuki Miyazaki, ${ }^{1}$ Ryuji Murayama, ${ }^{2}$ \\ Toshiaki Kodama, ${ }^{* * 1}$ Ikuo Kitamura, ${ }^{1}$ and Shuji Inoue ${ }^{3,4}$
}

\begin{abstract}
J Jpn Soc Nutr Food Sci 52:285-291 (1999)
In order to investigate the effect of commercially available wheat albumin (WA), which has inhibitory activity against human amylases, on postprandial blood glucose and insulin responses, 12 normal, 12 borderline and 22 diabetic volunteers were given cooked rice $(300 \mathrm{~g})$ with and without WA in a cross-over manner. WA was added to cooked rice at a dose of $1.5 \mathrm{~g}$. The dose contained $458 \mathrm{mg}$ of 0.19-albumin, the most dominant amylase inhibitor in WA. The administration of WA significantly lowered the mean blood glucose level $30 \mathrm{~min}$ and $1 \mathrm{~h}$ after the meal in the borderline and diabetic groups, but lowered the mean blood glucose level only $30 \mathrm{~min}$ after the meal in the normal group ( $p<$ 0.01 ). The mean area under the curve (AUC) of plasma glucose over $3 \mathrm{~h}$ was reduced by $22 \%$ in the diabetic group $(p<0.01), 19 \%$ in the normal group and $16 \%$ in the borderline groups, the latter two reductions being non-significant. WA also decreased serum insulin $1 \mathrm{~h}$ after the meal in the diabetic group $(p<0.01)$ and $30 \mathrm{~min}$ after the meal in the borderline $(p<0.05)$ group. No adverse reactions, e.g., abdominal pain, diarrhea, retching and flatus, were observed during the study period. Administration of $1.5 \mathrm{~g}$ of WA was able to suppress the rice meal-induced hyper glycemic response. Thus WA may be useful for preventing postprandial hyperglycemia in diabetic patient.
\end{abstract}

Key Words wheat albumin, amylase inhibition, postprandial hyperglycemia, impaired glucose tolerance, non-insulin-dependent diabetes mellitus.

(Received March 17, 1999 ; Accepted June 25, 1999)

現在増加している糖尿病の 95\%はインスリン非依存 性糖尿病であるが，その多くは軽症であり，その予備軍 である耐糖能異常を有する者も増加している。また，近
年，動脈硬化症，特に心筋梗塞との関連から，糖尿病 (耐糖能異常)，高脂血症，高血圧などの危険因子を一塊 とする病態を仮定し，その病態をシンドロームXある

* 小麦アルブミンによる食後血糖上昇抑制作用に関する研究（第 1 報）

** 連絡先・別刷請求先 (Corresponding author)

1 日清製粉株式会社ヘルスケアフーズ部（101-8441 東京都千代田区神田錦町 1-25）

Nisshin Flour Milling Co., Ltd., 1-25, Kanda-nishiki-cho, Chiyoda-ku, Tokyo 101-8411, Japan

2 長田産業株式会社（671-2544 兵庫県宍粟郡山崎町千本屋 215）

Nagata Sangyo Co., Ltd., Senbonya 215, Yamazaki-cho, Shiso-gun, Hyogo 671-2544, Japan

3 横浜市立大学医学部第三内科学教室 (236-0004 横浜市金沢区福浦 3-9)

Third Department of Internal Medicine, Yokohama Municipal University, 3-9 Fukuura, Kanazawa-ku, Yokohama 236-0004, Japan

4 現勤務先：国立健康・栄養研究所老人健康・栄養部（162-0052 東京都新宿区戸山 1-23-1）

Present address : Division of Geriatric Health and Nutrition, National Institute of Health and Nutrition, 1-23-1, Toyama, Shinjuku-ku, Tokyo 162-0052, Japan 
いは死の四重奏などと呼ぶようになったが，この病態の 共通点はインスリン抵抗性とそれに伴う高インスリン血 症の存在である。これらの観点から, 食後の急激な血糖 の上昇とそれに伴う高インスリン血症の是正が糖尿病ひ いては動脈硬化症の予防・治療上重要と考えられてい る。さらに, 糖尿病においては, 高血糖状態の持続が引 き起こすタンパク糖化（グリケーション）が合併症の進 展に大きく係わっていることが近年明らかになり ${ }^{1)}$, 食 後血糖値を含めたより厳格な血糖管理の重要性が認識さ れるようになった。

近年, 食後の血糖変化やインスリン分泌反応が，摂取 した糖質の種類や加工法によって異なることが示さ $れ^{223)}$, 食後血糖上昇がより穏やかな食品を選択摄取す る新しい食事療法の考元方が提案されている。Jenkins et $a l .{ }^{4)}$ は糖質を含む食品を摂取した後の食後血糖上昇 の大きさをグリセミックインデックス (GI) という数 值で表して食品の評価として応用することを提案した。 しかし食品交換として利用するための GI の導入に対し ては，たとえば複数の食品を同時に摂取した場合に個々 の食品の GI 值から食事全体の GI が導かれるか否か5), 食品の摂取量と GI の間に相関性があるか否が 問題が論議されている。

このような状況下において, 食物瀻維や糖質の消化吸 収に関わる酵素の阻害郕を用い, 糖質の消化吸収を遅延 または抑制して食後の血糖上昇を抑制する試みがなされ てきた。たとえば，水溶性食物繊維には糖質の吸収を物 理的に遅延させ，食後の血糖上昇を抑制する効果があ る7)。また $\alpha$-グリコシダーゼの阻害剤も食後血糖值の上 昇抑制効果が明らかになり ${ }^{8)}$, 糖尿病治療薬として現在 使用されている。

小麦アルブミン（WA）は小麦の水溶性タンパク画分 を抽出したもので, 主成分の 0.19-小麦アルブミン（電 気泳動における移動度による命名 $)^{9)}$ をはじめとして, 複数のタンパク質で構成されている。WA は従来, 食 品加工上の用途（肉製品の「つなぎ」など）で使用され てきたものであるが, 最近, 哺乳類のアミラーゼに対す る阻害活性を有し, 生体内で糖質の消化を遅延しうる可 能性が指摘されている(10)11)。

そこで本研究では, 小麦アルブミンの特性を明らかに し, さらに, 正常型, 境界型, 糖尿病型のボランティア に, 米飯負荷試験を実施し, WA の糖質消化の遅延作 用による血糖上昇抑制効果について検討した。また，そ の副作用についても検討した。

\section{試 験 方 法}

\section{1. 材料}

被験物質である小麦アルブミン（WA）は，日清製粉 株式会社より提供された。WA の抽出および 0.19 -小麦 アルブミンの精製は既報9. に従った。WA 中の 0.19-小 麦アルブミン含有率は $30.5 \%$ であった。

\section{WA のアミラーゼ活性阻害実験（in vitro）}

WA ならびに 0.19-小麦アルブミンのヒトアミラーゼ に対する阻害活性は, Kotaru et al. の方法 ${ }^{12)}$ に準じて 測定した。すなわち，加熱可溶性デンプンを基質とし， 反応後の残存デンプン量をヨウ素による発色で定量する アミラーゼ活性測定法であり, 規定活性量のアミラーゼ による反応を $50 \%$ 阻害する阻害活性を $1 U$ とし, 試料 重量 $(\mathrm{mg})$ 当りで表示した。ヒト膵液アミラーゼは Athens Research and Technology 社, ヒト唾液アミ ラーゼは Sigma 社よりそれぞれ入手した。

\section{WA のヒトにおける食後高血糖抑制試験 (in vivo)}

3.1 対象 ヒ卜試験に打ける被験者は，健常者なら びに, 糖尿病の疑いで医師の観察下にあった者の中から 募ったボランティア合計 46 例で, WA 投与前の空腹時 血糖值㧍よび $300 \mathrm{~g}$ 米飯負荷時の血糖值により, 以下の 基準で正常型, 境界型, 糖尿病型の 3 群に分けた。正常 型は, 空腹時血糖值 $110 \mathrm{mg} / \mathrm{dL}$ 末満, かつ負荷後の 1 時間值 $160 \mathrm{mg} / \mathrm{dL}$ 未満, かつ 2 時間值 $120 \mathrm{mg} / \mathrm{dL}$ 末満 の者とした。糖尿病型は空腹時血糖值 $140 \mathrm{mg} / \mathrm{dL}$ 以上, または 2 時間值 $200 \mathrm{mg} / \mathrm{dL}$ 以上の者とした。境界型は 両者の中間で, 正常型でも糖尿病型でもない者とした。 極端な肥満または瘦せ，重篤な疾病を有する者，胃切除 または腸管切除の既往, 穀物アレルギー体質の者など, 試験対象者として不適当と考えられる者は除外した。被 験者には試験の目的, 方法, 予想される効果, 参加しな くても不利益にはならないこと，プライバシーの保護に 関する事項などを説明した上で，本人の自由意志による 同意を得た。

3.2 試験方法 各被験者に, 3 日間以上の間隔を置 いて計 2 回の米飯負荷試験を実施し, そのうち 1 回は負 荷食（米飯 $300 \mathrm{~g}$ ) のみを摂取させる対照試験とし, 残 る 1 回は負荷食に $1.5 \mathrm{~g}$ の WA を混合して与えるWA 効果試験とした。対照試験とWA 効果試験の順には偏 りがないようクロスオーバーデザインとし，被験者には ぞちらの試験日にWA を摂取したかはわからないよう にした。試験前日の午後 9 時以降は水以外の飲食を禁 じ, 試験当日は空腹時採血を行った後, 午前 9 時に負荷 食を無糖の紅茶 $200 \mathrm{~mL}$ とともに摂取させ，負荷食摂取 の 0.5 時間後, 1 時間後, 2 時間後抢よび 3 時間後に採 血を行った。試験中は禁煙とした。

採血は前腕正中静脈より行い, 血漿のグルコース濃度 ならびに血清インスリン濃度（二抗体法）を測定した。 糖尿病型に分類された被験者については別途フルクトサ ミンならびに 1,5-アンヒドログルシトール $(1,5-\mathrm{AG})$ の測定を行った。また試験中の下痢, 放屁, 腹部膨満感 などの消化器症状の有無を観察し，記録した。

血糖値の AUC (Area Under the Curve：上昇面積值) は, 負荷後 3 時間の経時変化から幾何学的に算出した。 


\section{4. 統 計処 理}

検査データは平均 $\pm \mathrm{SE}$ (標準誤差）として表した。 背景データに関する平均值の差の検定は， $t$ 検定で行っ た。その他の項目に関しては, クロスオーバー法の分散 分析を行った後, 対象とする要因の分散比に有意性が見 られた場合, その要因に関して, Tukey-Kramer 法に より平均值の差の検定を行った。統計処理に関するソフ トウェアは, SAS-GLM (SAS software ver.6 SAS Institute Inc. USA）を用いて行った ${ }^{2021) 。}$

\section{結果}

\section{In vitro アミラーゼ阻害活性実験}

WA ならびに0.19-小麦アルブミンのヒトアミラーゼ に対する阻害活性を測定し，小麦粉（市販の薄力粉）と 比較したところ, Table 1 のごとくであった。WA は ヒトの唾液, 膵液両方のアミラーゼに対する阻害活性を 有し，比活性は唾液および膵液アミラーゼに対して，そ れぞれ小麦粉の 147 倍, 145 倍であった。0.19-小麦ア ルブミンは WA 中最も比活性が高い区分であり，小麦
粉の約 370 倍の比活性であった。WA 中の 0.19-小麦ア ルブミンの含有率から推定すると, WA が有する唾液 および萃液アミラーゼ阻害活性のそれぞれ $81 \%, 82 \%$ が 0.19-小麦アルブミンに由来していると考えられた。

Table 1 Inhibitory activity of wheat flour, wheat albumin and 0.19 -albumin against human salivary and pancreatic amylases.

\begin{tabular}{|c|c|c|c|}
\hline \multirow[t]{2}{*}{ Sample } & \multicolumn{2}{|c|}{$\begin{array}{c}\text { Amylase inhibitory } \\
\text { activity }(\mathrm{U} / \mathrm{mg})^{\mathrm{c}}\end{array}$} & \multirow{2}{*}{$\begin{array}{l}\text { Content or } \\
\text { purity of } \\
0.19 \text {-albumin } \\
\text { (\%) }\end{array}$} \\
\hline & \multicolumn{2}{|c|}{$\overline{\text { Salivary Pancreatic }}$} & \\
\hline Wheat flour ${ }^{a}$ & 53 & 54 & 0.09 \\
\hline Wheat albumin & 7770 & 7840 & 30.5 \\
\hline 0.19 -albumin ${ }^{\mathrm{b}}$ & 19800 & 20300 & 96.3 \\
\hline \multicolumn{4}{|c|}{$\begin{array}{l}\text { aCommercially available multi-purpose flour. } \\
\text { bPurified from wheat flour by the method of Maeda } \\
\text { et al. }{ }^{9} \text { c Determined by the method of Kotaru et al. }{ }^{22} \\
\text { dDetermined by reversed-phase high performance } \\
\text { liquid chromatography. }\end{array}$} \\
\hline
\end{tabular}

Table 2 Clinical characteristics of the 3 groups of subjects.

\begin{tabular}{lccc}
\hline \hline \multicolumn{1}{c}{ Group } & Normal & Borderline & Diabetic \\
\hline Number of subjects & 12 & 12 & 22 \\
Age (year) & $50.4 \pm 1.55$ & $48.5 \pm 2.11$ & $50.5 \pm 1.56$ \\
Height $(\mathrm{cm})$ & $167 \pm 1.8$ & $168 \pm 1.5$ & $169 \pm 2.0$ \\
Body weight $(\mathrm{kg})$ & $71 \pm 2.2$ & $69 \pm 1.9$ & $68 \pm 2.3$ \\
BMI & $25.2 \pm 0.43$ & $24.4 \pm 0.56$ & $23.7 \pm 0.68$ \\
Fasting plasma & $96 \pm 3.0^{\mathrm{a}}$ & $116 \pm 1.4^{\mathrm{b}}$ & $151 \pm 5.9^{\mathrm{c}}$ \\
$\quad$ glucose $(\mathrm{mg} / \mathrm{dL})$ & & & $301 \pm 9.7$ \\
Fructosamin $(\mu \mathrm{mol} / \mathrm{L})$ & & $9.4 \pm 1.60$ \\
$1,5-\mathrm{AG}(\mu \mathrm{g} / \mathrm{mL})$ & & & \\
\hline \hline
\end{tabular}

Mean \pm SE. ${ }^{\text {a,b,c }}$ Groups not sharing the alphabets are significantly different at $p<0.05$.

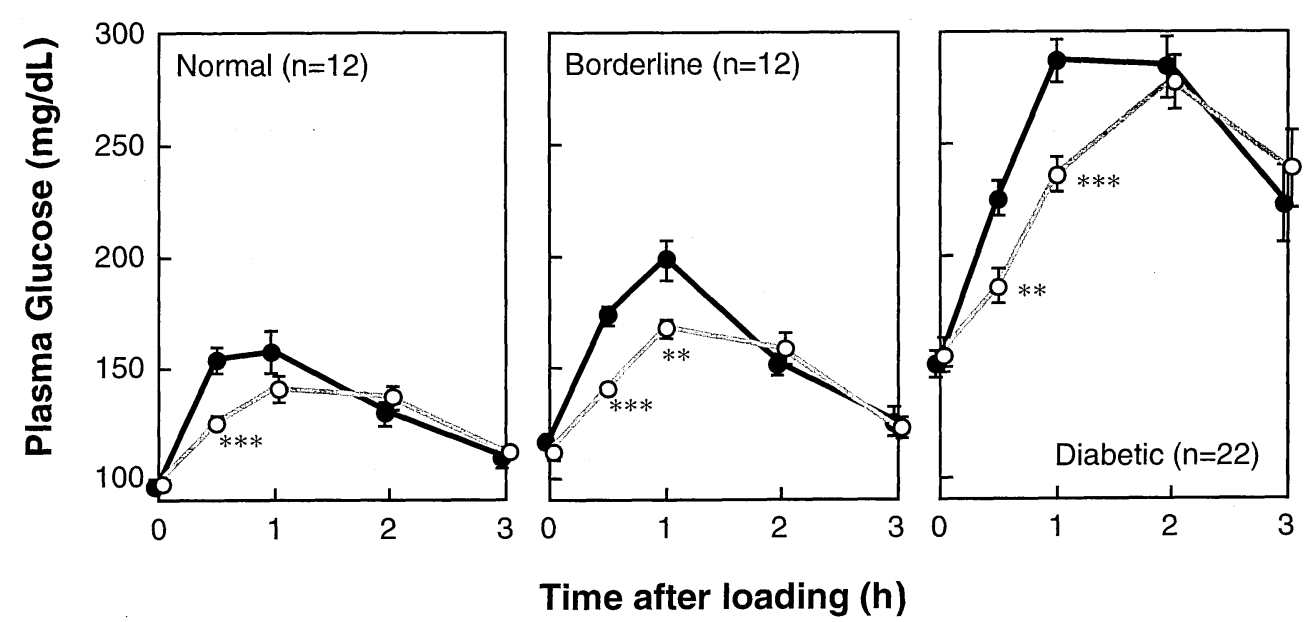

Figure 1 Effect of wheat albumin (WA) on the glycemic responses to cooked rice loading in normal, borderline and diabetic humans.

Overnight fasted subjects were given $300 \mathrm{~g}$ cooked rice (•, cooked rice only) and blood samples were taken at $0,0.5,1,2$, and $3 \mathrm{~h}$ after the loading. WA was mixed into cooked rice $(\bigcirc)$ and administered at a dose of $1.5 \mathrm{~g}$. The values are in mean $\pm \mathrm{SE} .{ }^{*} p<0.05 ;{ }^{* *} p<0.01 ;{ }^{* * *} p<0.001$ for the difference from the values of the loading of cooked rice only. 


\section{2. 米飯負荷試験の被験者の背景}

被験者は 34 歳から 63 歳までの男性 46 例で，正常型 12 例, 境界型 12 例, 糖尿病型 22 例に分類された。各 型の年齢, 身長, 体重, BMIには差は見られなかった (Table 2)。また, 糖尿病型の被験者中に, 経口剂また はインスリンによる治療を受けている者はいなかった。

\section{3. 血糖值変化に対する WA 摂取の影響}

負荷食のみによる対照試験における血糖変化は，正常 型および境界型では負荷 1 時間後に頂点に達し, その際 の上昇幅は正常型で $61 \pm 9.7 \mathrm{mg} / \mathrm{dL}$ ，境界型で $83 \pm 8.1$ $\mathrm{mg} / \mathrm{dL}$ であった（Figure 1, ○）。糖尿病型では負荷 1 時 間後から 2 時間後にかけて $250 \mathrm{mg} / \mathrm{dL}$ を超す高血糖が 持続し，上昇幅は 1 時間值で $135 \pm 4.8,2$ 時間值で $133 \pm 10.0 \mathrm{mg} / \mathrm{dL}$ であった。

負荷食とWA を混合食として摂取させたWA 効果試 験では, 境界型, 糖尿病型においては負荷 0.5 時間後と 1 時間後の血糖值が対照と比べて有意に低下し（ $p<$ $0.01 ）$ 正常型においても負荷 0.5 時間後の血糖值が有意 に低下しており $(p<0.001)$ ，いずれの型においても血 糖上昇抑制が認められた（Figure 1,0$)$ 。正常型および 境界型ではWA 摂取時も血糖值の頂点は負荷 1 時間後 にあり，その際の上昇幅はそれぞれ $43 \pm 5.3 \mathrm{mg} / \mathrm{dL}$ お よび $56 \pm 4.7 \mathrm{mg} / \mathrm{dL}$ であり，対照と比べた上昇抑制率 は正常型で 30\%, 境界型では 33\%であり，境界型では 有意に抑制された $(p<0.01)$ 。糖尿病型では血糖值の 頂点が負荷 2 時間後へと遅延し，血糖上昇幅は $10 \%$ 減 少して $122 \pm 8.7 \mathrm{mg} / \mathrm{dL}$ となったが，この抑制は有意な 変化ではなかった。

血糖值の AUC は WA 混合食により, 対照と比べて 正常型では 19\%, 境界型では 16\%の減少となったが, この抑制は有意ではなかった（Figure 2)。一方，糖尿

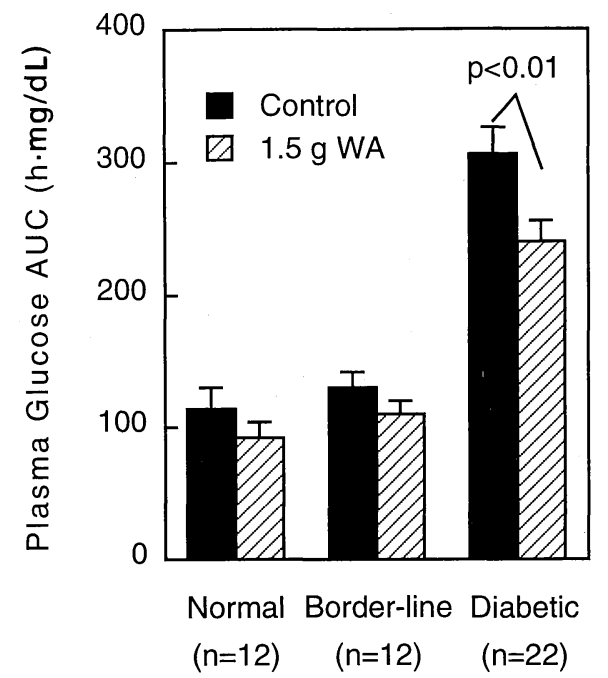

Figure 2 Effect of wheat albumin (WA) on plasma glucose AUC (area under curve) for $3 \mathrm{~h}$ after cooked rice loading in normal, borderline and diabetic humans.

Overnight fasted subjects were given $300 \mathrm{~g}$ cooked rice ( $\boldsymbol{\square}$, cooked rice only) and blood samples were taken for $3 \mathrm{~h}$. WA was mixed into cooked rice $(\mathbb{U})$ and administered at a dose of $1.5 \mathrm{~g}$. The values are in mean $\pm \mathrm{SE}$.

病型ではWA 混合食により有意な $22 \%$ の減少を示した $(p<0.01)$ 。

\section{4. 血清インスリン濃度変化に対する WA 摂取の 影響}

対照試験における血清インスリン濃度変化は，境界型 ならびに糖尿病型で正常型より初期分泌が弱い傾向が見 られたが，頂值には 3 群間で差が見られなかった（Figure $3, \bullet$ )。

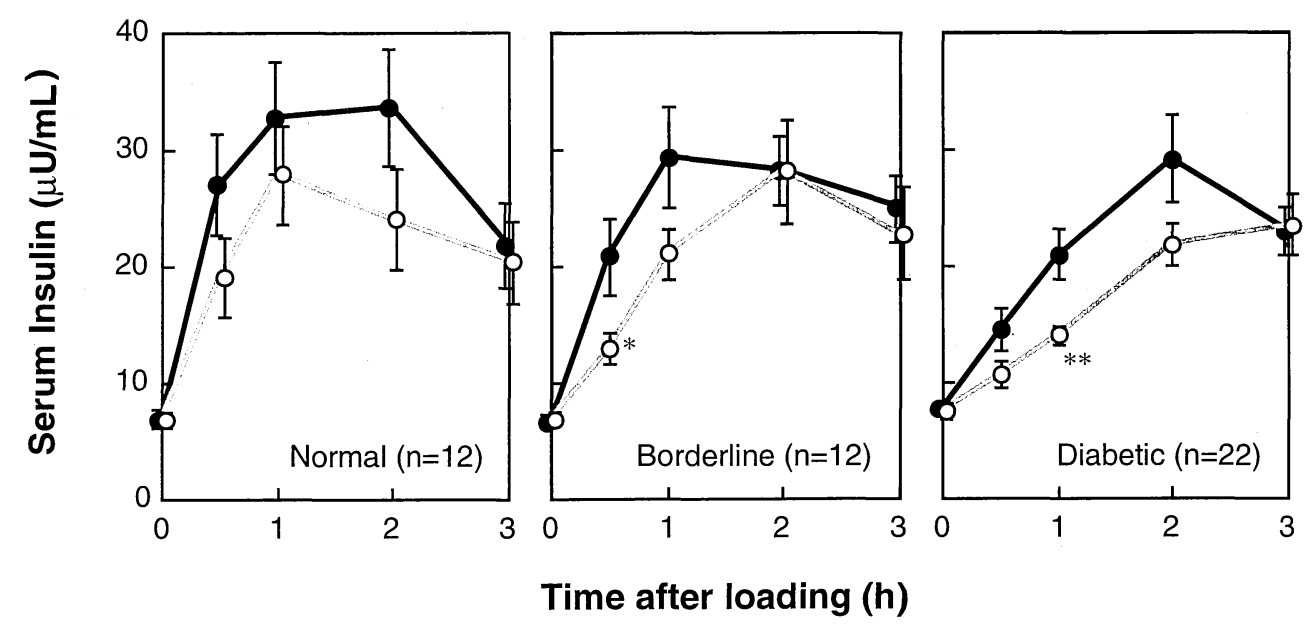

Figure 3 Effect of wheat albumin (WA) on serum insulin after cooked rice lading in normal, borderline and diabetic humans.

Overnight fasted subjects were given $300 \mathrm{~g}$ cooked rice (•, cooked rice only) and blood samples were taken at $0,0.5,1,2$, and $3 \mathrm{~h}$ after the loading. WA was admixed into cooked rice $(\bigcirc)$ and administered at a dose of $1.5 \mathrm{~g}$. The values are in mean $\pm \mathrm{SE} .{ }^{*} p<0.05 ;{ }^{* *} p<0.01 ;{ }^{* *} p<0.001$ for the difference from the values of the loading of cooked rice only. 
WA 混合食摂取時には正常型，境界型，糖尿病型い ずれの群も，対照に比べて負荷後の上昇が抑制される傾 向にあった（Figure 3，O）。境界型では負荷 30 分後に おいて対照よりWA 摂取時の方が有意に低かった（ $p<$ 0.05)。糖尿病型では負荷 1 時間後において有意な抑制 が認められた $(p<0.01)$ 。正常型では有意差は見られ なかった。

\section{5. 消化器症状など}

全試験を通じて下㾝，放屁，腹部膨満感などの消化器 症状，その他の症状は観察されなかった。

\section{考察}

小麦やインゲン豆の種子に含まれるタンパク質が動物 のアミラーゼに対する阻害活性を有していることは古く から知られていた。Puls \& Keup ${ }^{13)}$ は小麦のグリアジン 画分（アルブミンとは異なり，含水アルコールで抽出さ れる画分）から調製したアミラーゼ阻害物質をラット， イヌ，ヒトに与え，糖質消化の遅延により糖質摂取後の 血糖值の上昇が抑制されることを報告した。その後，ア ミラーゼ阻害物質の生理的作用に関する研究はインゲン 豆由来のものが対象となり，血糖上昇抑制作用および肥 満防止作用が検討され，Layer et $a l .{ }^{14)}$ は十分な量を投 与すれば糖質摂取後の血糖上昇を抑制できることを明ら かにした。しかし同時に投与量依存的な下痢の発生も報 告され ${ }^{15)}$ ，インゲン豆実用化の試みは実用化には至って いない。

本研究で使用したWA は既に食品として使用されて いる素材であり，有用性が確認されれば，実用性は非常 に高いと考えられる。その主成分である0.19-小麦アル ブミンは小麦の肧乳（食用部分）に含まれる水溶性タン パク質の中で最も含有量の多いものとして早くから研究 され，アミラーゼ阻害活性を有していることも知られて いた ${ }^{16)}$ 。しかし従来の合成基質を用いた研究9)では, 0.19-小麦アルブミンのアミラーゼ阻害活性は唾液アミ ラーゼに特異的であり, 糖質の消化への寄与が大きい膵 液アミラーゼに対する阻害活性は弱いとされていた。こ のため0.19-小麦アルブミンの血糖上昇抑制作用および 肥満防止作用の検討は本格的になされてこなかった。し かし，基質に加熱可溶性デンプンを用いた本研究の特性 試験では，WA ならびに0.19-小麦アルブミンに唾液, 膵液両方のアミラーゼを阻害する活性が認められた。食 事に含まれる糖質のほとんどは加熱を受けたデンプンで あることから，本特性試験結果の方が，実際の生体内で の作用を反映しているものと考えられる。WAに含ま れる唾液, 膵液アミラーゼ阻害活性の $80 \%$ 以上が 0.19 小麦アルブミンに由来していたことから，0.19-小麦ア ルブミンはWA の作用本体とみなすことができる。

$1.5 \mathrm{~g}$ のWA（0.19-小麦アルブミンとして $458 \mathrm{mg}$ 相 当）を $300 \mathrm{~g}$ の米飯とともに摂取させたところ，正常 型, 境界型, 糖尿病型のいずれの群の被験者においても
食後の血糖上昇が抑制され，同時に血清インスリン濃度 の上昇も境界型と糖尿病型で抑制された。糖尿病型では WA 捸取により血糖值 AUC が有意に低下し, 正常型・ 境界型においてはWA 捸取による血糖值 AUCの低下 は有意ではなかったが，30 分後，1時間後の血糖値は有 意に抑制されており，血清インスリン濃度も正常型では 有意差はなかったが低下傾向が見られ，境界型では 30 分後に有意な低下を示し，糖尿病型では 1 時間後に有意

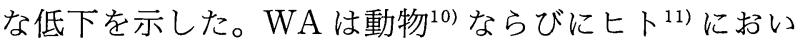
て，消化管内のアミラーゼ活性を一時的に低下させ，糖 質の消化吸収を遅延させる作用が確認されていることか ら，本研究に拉いても米飯の消化が遅延され，その結 果，血中へのグルコースの放出速度が低下し，血糖上昇 が抑制されたものと推察された。またインスリンは血糖 上昇に応じて分泌されるため，血糖上昇の抑制に伴い内 因性インスリン分泌需要の軽減が見られたものと考えら れた。なお，WAの適切な摂取量の設定に関してはさ らに検討を待たなければならないと考えられる。

本研究における糖尿病型の被験者は, 緩慢ながらもイ ンスリン分泌が認められること，フルクトサミンならび に 1,5-AG の值，および食事療法対象者であることなど から，比較的軽症の患者である。境界型や軽症の糖尿病 患者におけるWAの効果が確認されたことは，糖尿病 患者または予備軍対象者に対して，WA を食事と同時 に摂取すると食後高血糖を抑制できることを示唆する所 見と考えられる。インスリン非依存性糖尿病患者では, 糖質を摂取した直後のインスリン分泌が遅れる傾向があ り，WA はこのようなインスリン分泌遅延応答にグル コース吸収速度を適合させると同時に，より低いインス リン濃度で血糖值をコントロールすることにつながるも のと考えられる。また，インスリン需要量を減少させる ことは, 膵 $\beta$ 細胞の疲弊を防ぐ作用も発揮するものと 考えられる。

前述のインゲン豆由来アミラーゼ阻害物質を用いた研 究15) では，糖質消化の遅延に伴い投与量依存的な下痢 の発生が報告されているが，本研究においては消化器症 状の発生は見られなかった。インゲン豆由来の阻害物質 は糖タンパク質であり，タンパク質分解酵素に対する耐

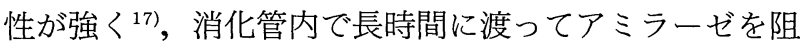
害し続けると考えられるのに対し，WAの主成分であ る 0.19-小麦アルブミンは単純タンパク質で9), タンパ ク質分解酵素により速やかにに消化され，糖質の消化を 遅延しうるようなアミラーゼの阻害は捸取後短時間しか 持続しないと報告されている ${ }^{10)}$ 。この性質により，WA はインゲン豆由来のアミラーゼ阻害物質で見られたよう な消化器症状を伴わずに血糖上昇を抑制できたものと推 察される。

本研究におけるWAの摂取量, $1.5 \mathrm{~g}$ は, アミラーゼ 阻害活性から，小麦粉では約 $200 \mathrm{~g}$ の摂取に相当すると 考えられ，実際にその程度の量の小麦粉の摂取は不自然 
ではない。かつ, 小麦由来のアミラーゼ阻害タンパク質 は熱安定性が高く ${ }^{18)}$, 小麦粉の調理によっても完全には 失活しない性質をもっている ${ }^{19)}$ 。小麦粉の摂取による消 化器症状の発生が従来から問題とはならないのは, 上記 の理由によるものと推察される。

なお， $\alpha$-グリコシダーゼ阻害剤による糖質消化の阻 害では, 低分子糖類が腸管内に蓄積し浸透圧性の下痢を 誘発しやすいのに対し，アミラーゼの阻害では低分子糖 類の蓄積が起こらないため, この点でも安全性は高いと 推察される。

本研究の結果は, これまでインゲン豆由来のアミラー ゼ阻害物質や小麦のグリアジン系アミラーゼ阻害物質で 認められていた血糖上昇抑制作用が WA でも期待でき ること, そしてインゲン豆由来アミラーゼ阻害物質や $\alpha$-グリコシダーゼ阻害剤で問題となっていた消化器症 状がWA では見られないことを示すと同時に，WAの 糖尿病の予防および治療に打ける食事療法の補助手段と しての臨床的な有用性を示唆したものである。

\section{要約}

小麦粉の水溶性タンパク質画分を抽出・分離した小麦 アルブミン（WA）はアミラーゼ阻害活性を有し, 糖質 の消化吸収を遅延させる。WA は小麦粉の約 150 倍の ヒト唾液ならびに膵液アミラーゼに対する阻害活性を有 しており，その作用本体は 0.19-アルブミンと呼ばれる 既知のタンパク質であった。本研究は米飯摂取後の血糖 上昇ならびにインスリン分泌に対するWAの影響を正 常型 (12 例), 境界型 (12 例), 糖尿病型 (22 例) に属 する被験者で検討した。各被験者に $300 \mathrm{~g}$ 米飯負荷試験 を 2 回ずつ実施し，クロスオーバーで 1 回は対照とし， 残る 1 回に $1.5 \mathrm{~g}$ の WA を米飯に混合して摂取させた。 WA 攝取時は対照に比べ, 正常型, 境界型, 糖尿病型 いずれの型においても血糖上昇の抑制が見られ，境界型 および糖尿病型の負荷 30 分後および 1 時間後の血糖值 は有意の低下を示し $(p<0.01)$, 正常型でも負荷 30 分 後の血糖値は有意の低下を示した $(p<0.01)$ 。負荷 3 時間後までの血糖值 AUC（上昇面積值）は糖尿病型で 有意に減少し（減少率 $22 \%, p<0.01$ ）, 正常型，境界 型でも減少傾向が見られた。血糖上昇の抑制に相応して 血清インスリン濃度も低く推移し, 境界型の負荷 30 分 後 $(p<0.05)$ および糖尿病型の負荷 1 時間後 $(p<$ 0.01）には有意の減少が見られた。WA 摂取による腹 痛, 下痢, 放屁などの消化器症状は観察されなかった。 WA 捸取により, 消化器症状を伴わずに, 米飯摂取後 の血糖上昇が抑制され，食後高血糖の予防にWA 捸取 が有用である可能性が示された。

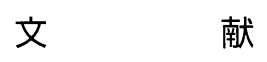

1) Cohen MP (1986) Diabetes and Protein Glycosylation: Measurement and Biologic Relevance.
Springer-Verlag, New York.

2) Crapo PA, Reaven G, Olefsky J (1977) Postprandial plasma-glucose and -insulin responses to different complex carbohydrates. Diabetes 26 : 1178-83.

3) Coulston A, Greenfield MS, Kraemer FB, Tobey TA, Reaven GM (1980) Effect of source of dietary carbohydrate on plasma glucose and insulin responses to test meals in normal subjects. $A m \mathrm{~J}$ Clin Nutr 33:1279-82.

4) Jenkins DJA, Wolever TMS, Taylor RH, Barker $\mathrm{H}$, Hashmein F, Baldwin JM, Bowling AC, Newman HC, Jenkins AL (1981) Glycemic index of foods: A physiological basis for carbohydrate exchange. Am J Clin Nutr 34 : 362-66.

5) Wolever TMS, Jenkins DJA (1986) The use of the glycemic index in predicting the blood glucose response to mixed meals. Am J Clin Nutr 43 : 167-72.

6) Rasmussen O, Gregersen S, Hermansen K (1992) Influence of the amount of starch on the glycemic index to rice in non-insulin-dependent diabetic subjects. Br J Nutr $67: 371-77$.

7) Doi K, Matsuura M, Kawara A, Baba S (1979) Treatment of diabetes with glucomannnan. Lancet $1: 987-88$.

8) Puls W, Keup U, Krause HP, Thomas G, Hottmeister F (1977) Glucosidase inhibition. A new approach to the treatment of diabetes, obesity, and hyperlipoproteinaemia. Naturwissenschaften 64:536-7.

9) Maeda K, Kakabayashi S, Matsubara H (1985) Complete amino acid sequence of an $\alpha$-amylase inhibitor in wheat kernel (0.19-inhibitor). Biochim Biophys Acta 828 : 213-21.

10) Koike D, Yamadera K, DiMagno EP (1995) Effect of a wheat amylase inhibitor on canine carbohydrate digestion, gastrointestinal function and pancreatic growth. Gastroenterology 108 : 1221-9.

11) Choudhuty A, Maeda K, Murayama R, DiMagno EP (1996) Character of a wheat amylase inhibitor preparation and effects on fasting human pancreaticobiliary secretions and hormones. Gastroenterology $111: 1313-20$.

12）小垂 眞, 木本文喜, 吉川秀樹, 池内常郎 (1987) 加熱時および発芽時におけるインゲン豆の $\alpha$-アミ ラーゼインヒビター活性の変化. 日本栄養・食糧学 会誌 40,240-3.

13) Puls W, Keup U (1973) Influence of an $\alpha$ amylase inhibitor on blood glucose, serum insulin and NEFA in starch loading tests in rats, dogs and man. Diabetologia 9:97-101.

14) Layer P, Carlson GL, DiMagno EP (1985) Partially purified white bean amylase inhibitor reduse starch digestion in vitro and inactivates intraduodenal amylase in humans. Gastroenterology $88: 1895-902$. 
15) Boivin M, Zinsmeister AR, Go VLW, DiMagno EP (1987) Effect of a purified amylase inhibitor on carbohydrate metabolism after a mixed meal in healthy humans. Mayo Clinic Proc $62: 249-255$.

16) Silano V, Pocchiari F, Kasaruda DD (1973) Physical characterization of $\alpha$-amylase inhibitors from wheat. Biochim Biophys Acta 317: 139.

17) Kotaru M, Iwami K, Yeh HY, Ibuki F (1991) Resistance of cranberry bean (Phaseolus vulgaris) $\alpha$-amylase inhibitor to intraluminal digestion and its movement along rat gastrointestine: Further investigation using a radioactive probe and specific antiserum. Food Chem $42: 29-37$.

18) Silano V, Zahnley JC (1978) Association of tenebrio molitor L. $\alpha$-amylase with two protein in- hibitors, one monometric, one dimetric from wheat flour. Biochim Biophys Acta 533:181-5.

19）別所秀子, 黒沢祝子（1967）食品中の酵素インヒビ ターについての調理学的研究 (第 3 報). 栄養と食 糧 20, 317-9.

20）高橋行雄, 大橋靖雄, 芳賀敏郎（1989）SASによ る実験デー夕の解析，p. 129-38. 東京大学出版会, 東京.

21）(株サイエンスティチュートジャパン (1995) SAS/ STAT ソフトウェア：ユーザーズガイド Ver. 6, 569-666.

(1999 年 3 月 17 日受付, 1999 年 6 月 25 日受理) 